\title{
PENGARUH METODE IQRA \\ DALAM PELAJARAN MEMBACA AKSARA SUNDA TERHADAP KEMAMPUAN MENULIS AKSARA SUNDA
}

\author{
Herni Apriani \\ SMK Pasundan Subang \\ Pos-el: apriani_herni@ymail.com
}

\begin{abstract}
ABSTRAK
Penelitian ini dilatarbelakangi oleh adanya kesulitan membaca dan menulis aksara Sunda sering dialami oleh siswa karena metode pembelajaran yang digunakan oleh guru kurang sesuai dengan kompetensi dasar yang diajarkan. Adapun tujuan dari penelitian ini adalah untuk mendeskripsikan (1) metode iqra dalam pembelajaran membaca aksara Sunda, (2) kemampuan awal dan akhir membaca aksara Sunda, (3) kemampuan awal dan akhir menulis aksara Sunda, dan (4) pengaruh metode iqra dalam pembelajaran membaca aksara Sunda terhadap kemampuan menulis aksara Sunda. Metode yang digunakan dalam penelitian ini yaitu metode deskriptif, sedangkan tehnik yang digunakan untuk pengumpulan dan pengolahan data yaitu tehnik tes. Sumber data dalam peneltian ini yaitu siswa kelas X SMK Pasundan Subang yang berjumlah 36 orang. Hasil penelitian ini adalah (1) nilai rata-rata kemampuan awal membaca aksara Sunda $(40,33)$ dan kemampuan akhir $(86,78)$, dan (2) nilai rata-rata kemampuan awal menulis aksara Sunda $(40,78)$ dan kemampuan akhir $(87,22)$, Peningkatan membaca dan menulis aksara Sunda juga dapat di lihat dari hasil uji hipotesis yang menunjukan $X^{2}$ hitung $\leq X^{2}$ tabel $-63,31 \leq 7,81$ untuk kemampuan membaca aksara Sunda, dan $X^{2} h$ itung $\leq X^{2}$ tabel yaitu $22,54 \leq 7,81$ untuk kemampuan menulis aksara Sunda. Berdasarkan hasil tersebut, dapat disimpulkan bahwa adanya pengaruh metode iqra dalam pembelajaran membaca aksara Sunda terhadap kemampuan menulis aksara Sunda siswa SMK Pasundan Subang.
\end{abstract}

Kata Kunci: Metode Iqra, Membaca, Menulis, Aksara Sunda.

\section{THE EFFECT OF IQRA METHOD IN THE LEARNING OF READING SUNDANESE ALPHABET ON THE ABILITY OF WRITING SUNDANESE ALPHABET}

\begin{abstract}
This research is motivated by the difficulties of reading and writing Sundanese alphabet experienced by students. It is the caused by the learning method used by the teacher, which is not in accordance with the basic competencies. The purpose of this study was to describe (1) the Iqra method in learning reading Sundanese alphabet; (2) the initial and final ability of reading Sundanese alphabet; (3) the initial and final ability of writing Sundanese alphabet; and (4) the effect of the iqra method in Sundanese alphabet learning on the ability of writing Sundanese alphabet. This research used descriptive method. The data Collection and processing employed a test technique. Source of data in this research is 36 students of Grade $X$ of SMK Pasundan Subang. The results show (1) the average value of initial ability (40.33) and the final ability (86.78) of reading Sundanese alphabet; and (2) the average initial ability (40.78) and the average final ability (87.22) of reading Sundanese alphabet. The improved ability of reading and writing Sundanese alphabet can be seen from the results of the hypothesis test. $X^{2}$ count $\leq X^{2}$ table $(-63.31 \leq 7.81)$ for the ability to read Sundanese alphabet,
\end{abstract}


and $X^{2}$ count $\leq X^{2}$ table i.e. $22.54 \leq 7,81$ for the ability to write Sundanese alphabet. Based on these results, the iqra method in learning reading Sundanese alphabet gives influence on the ability of writing Sundanese alphabet in SMK Pasundan Subang.

Keywords: Iqra Method, Reading, Writing, Sundanese Alphabet

\section{PENDAHULUAN}

Membaca dan menulis merupakan bagian dari keterampilan berbahasa selain berbicara dan menyimak. Kemampuan membaca merupakan salah satu jenis keterampilan berbahasa yang bersifat menerima, dan kemampuan menulis merupakan jenis keterampilan berbahasa yang bersifat produktif, artinya kemampuan menulis ini merupakan kemampuan bahasa tulis yang bisa menghasilkan tulisan. Dalam membaca dan menulis diperlukan media yang disebut aksara. Aksara daerah masyarakat Sunda adalah aksara Sunda Kaganga.

Masyarakat Sunda modern pada masa sekarang ini sudah tidak mengenal aksara Sunda, maka salah satu upaya pelestariannya dilakukan melalui pendidikan formal. Mulok Bahasa Sunda sebagai salah satu mata pelajaran wajib ti tingkat pendidikan dasar hingga menengah atas, memasukan pembelajaran aksara Sunda dalam kompetensi dasarnya.

Kompetensi Inti dan Kompetensi Dasar Mata Pelajaran Bahasa dan Sastra Sunda disusun berdasarkan Peraturan Daerah Provinsi Jawa Barat no. 5 Tahun 2003 tentang pemeliharaan Bahasa, Sastra, dan Aksara Daerah yang menetapkan bahasa daerah, antara lain bahasa Sunda, diajarkan di Pendidikan dasar di seluruh kabupaten kota di Jawa Barat. Kebijakan tersebut dikeluarkan bedasar kepada UU no.22/1999 tentang Pemerintahan Daerah dan UU no.20/2003 tentang Sistem Pendidikan Nasional yang bersumber dari UndangUndang 1945 mengenai Pendidikan dan Kebudayaan. Peraturan Pemerintah Republik Indonesia no.19 Tahun 2005 tentang standar Nasional Pendidikan yang menyatakan bahwa dari tingkat dasar sampai tingkat menengah atas diberikan pengajaran muatan lokal yang relevan. SKKD ini diputuskan oleh Gubernur Jawa Barat dengan nomor 423.5/Kep.674Disdik/2006. Selanjutnya mengenai keberadaan dan fungsi aksara Sunda dalam kehidupan sosial budaya masyarakat Jawa Barat umumnya masyarakat Sunda, dikeluarkannya Surat Keputusan Gubernur Kepala Daerah Tingkat I Jawa Barat No. 434/SK.614/dis-pk/1999 mengenai Pembakuan Aksara Sunda sebagai upaya nyata dari pemerintah dalam memelihara, mengembangkan dan memanfaatkan nilainilai kearifan lokal.

Di tingkat menengah atas (SMK), pembelajaran aksara Sunda terdapat di semester kedua kelas X. Khusus di SMK Pasundan Subang, pembelajaran aksara Sunda juga dipelajari dalam mata pelajaran Ciri Khas Pasundan untuk siswa kelas X semester kedua agar siswa lebih memahami aksara Sunda. Kemampuan membaca dan menulis aksara Sunda siswa SMK Pasundan Subang tergolong masih rendah. Rendahnya kemampuan membaca dan menulis aksara Sunda disebabkan oleh beberapa hal. Di antaranya yaitu pembelajaran yang masih menggunakan metode ceramah atau penugasan. Dapat dikatakan, pembelajaran masih didominasi oleh Guru (teacher center), sehingga siswa kurang menyerap materi pembelajaran dan merasa bosan karena proses pembelajaran yang monoton dan kurang menyenangkan. Oleh karena itu, sebaiknya guru menggunakan metode yang tepat untuk menyampaikan materi aksara Sunda untuk memudahkan siswa memahami dan membedakan bentukbentuk aksara Sunda.

Berdasarkan hal tersebut, metode pembelajaran yang saat ini umum digunakan bisa dibantu dengan media pembelajaran. Bisa dengan media 
pembelajaran interaktif melalui aplikasi aksara Sunda unicode, aplikasi seseratan android, dan aplikasi aksara Sunda digital yang sudah tersedia saat ini agar para siswa dapat mengingat dan memahami aksara Sunda dengan metode yang berbeda. Sayangnya, tidak semua siswa bisa mengakses aplikasi tersebut terkait fasilitas sekolah yang kurang memadai dan keadaan sosial ekonomi siswa SMK Pasundan Subang.

Salah satu metode yang dapat meningkatkan kemampuan membaca dan menulis aksara Sunda adalah dengan metode iqra. Metode iqra dalam pembelajaran aksara Sunda adalah metode membaca yang menekankan pada latihan membaca aksara Sunda tanpa mengeja. Terdiri dari enam jilid, jilid pertama latihan membaca dan menulis aksara vokal, jilid kedua latihan membaca dan menulis aksara konsonan (ngalagena), jilid ketiga latihan membaca dan menulis angka, jilid keempat latihan membaca dan menulis kalimah, jilid kelima latihan membaca dan menulis wacana, dan jilid keenam latihan menyalin aksara Sunda dari aksara latin dan sebaliknya.

Metode iqra adalah suatu metode membaca Al-Qur'an yang menekankan langsung pada latihan membaca. Adapun buku panduan iqra terdiri dari 6 jilid, mulai dari tingkat yang sederhana, tahap demi tahap sampai pada tingkatan yang sempurna. Metode iqra ini dalam prakteknya tidak membutuhkan alat yang bermacam-macam, karena ditekankan pada bacaannya (membaca huruf Al-Qur'an dengan fasih). Bacaan langsung tanpa dieja. Artinya diperkenalkan nama-nama huruf hijaiyah dengan cara belajar siswa aktif (CBSA) dan lebih bersifat individual. Metode pembelajaran ini pertama kali disusun oleh Humam (2000) di Yogyakarta. Buku metode iqra ini disusun/dicetak dalam enam jilid sekali. Di mana dalam setiap jilidnya terdapat petunjuk mengajar dengan tujuan untuk memudahkan setiap siswa yang akan menggunakannya, maupun ustadz/ustadzah yang akan menerapkan metode tersebut kepada santrinya. Metode iqra ini termasuk salah satu metode yang cukup dikenal di kalangan masyarakat, karena metode ini sudah umum digunakan di tengah-tengah masyarakat Indonesia.

Masalah yang akan dicari jawabannya melalui penelitian ini dirumuskan sebagai berikut: (1) proses pembelajaran meode iqra aksara Sunda; (2) kemampuan awal dan akhir membaca aksara Sunda siswa SMK Pasundan Subang sebelum dan sesudah menggunakan metode iqra; (3) kemampuan awal dan akhir menulis aksara Sunda siswa SMK Pasundan Subang sesudah menggunakan metode iqra; (3) pengaruh kemampuan menulis aksara Sunda dalam pembelajaran membaca aksara Sunda setelah menggunakan metode iqra; kemampuan membaca dan menulis aksara Sunda sesudah menggunakan metode iqra.

Penelitian ini bertujuan untuk: (1) mendeksripsikan proses pembelajaran metode iqra dalam aksara Sunda; (2) mendeskripsikan kemampuan awal dan akhir siswa dalam membaca dan aksara Sunda sebelum dan sesudah menggunakan metode iqra; (3) mendeskripsikan kemampuan awal dan akhir menulis aksara Sunda siswa meningkatnya kemampuan siswa sebelum dan sesudah menggunakan metode iqra; dan (4) ada tidaknya pengaruh metode iqra terhadap kemampuan menulis aksara Sunda dalam pembelajaran membaca aksara Sunda dengan menggunakan metode iqra.

Adapun manfaat dari penelitian ini secara teoritis berguna untuk menambah teori keterampilan berbahasa dan teori pembelajaran bahasa Sunda, dan bisa memberi informasi dalam sistem pendidikan, khususnya dalam memilih metode yang efektif dalam pembelajaran membaca dan menulis aksara Sunda. Dan secara praktis dapat menjadi metode alternatif untuk meningkatkan kemampuan 
siswa dalam membaca dan menulis aksara Sunda.

\section{METODE}

Metodologi dalam penelitian ini adalah penelitian kuantitatif dengan menggunakan metode kuasi eksperimen untuk menjawab hipotesis yang sudah dirumuskan karena analisis datanya mempunyai sipat kuantitatif dan statistik. Metode kuasi eksperimen atau disebut juga eksperimen semu yaitu penelitian yang menggunakan kelas eksperimen tanpa kelas kontrol. Metode kuasi eksperimen yang digunakan dalam penelitian ini dengan pre-test and post-test group, yaitu penelitian terhadap satu kelompok tanpa kelompok pembanding dengan tujuan bisa mengetahui tingkatan kemampuan siswa dalam membaca dan menulis aksara Sunda setelah menggunakan metode iqra. Jenis data yang digunakan dalam penelitian ini adalah data primer yaitu data hasil tes sebelum metode iqra dan data hasil tes setelah digunakannya metode iqra.

Tabel 1. Desain Penelitian

\begin{tabular}{ccc}
\hline Prates & Perlakuan & Postes \\
\hline O $_{1}$ & $\mathrm{X}$ & $\mathrm{O}_{2}$ \\
\hline & & (Arikunto, 2010:124)
\end{tabular}

Penelitian ini terdiri dari variabel bebas yaitu metode iqra serta variabel terikat yaitu kemampuan membaca dan menulis aksara Sunda.

Tehnik pengumpulan data dalam penelitian ini adalah dengan tehnik tes untuk mengetahui kemampuan awal dan akhir siswa dalam membaca dan menulis aksara Sunda. Tes berlangsung empat kali yang terdiri dari tes awal membaca, tes awal menulis, tes akhir membaca, dan tes akhir menulis.

Soal tes membaca bertujuan untuk mengetahui kemampuan awal dan akhir membaca. Setiap siswa dites membaca wacana yang ditulis dalam aksara Sunda secara bergantian. Masing-masing siswa secara acak dipanggil guru untuk membaca soal tes berhadapan dengan guru selama 10 menit. Siswa yang lainnya menunggu di luar menunggu giliran. Sedangkan dalam soal tes menulis, siswa secara bersamasama, menyalin wacana yang ditulis dalam aksara latin, untuk disalin ke dalam tulisan aksara Sunda selama 30 menit untuk tes awal, dan 20 menit untuk tes akhir.

Data yang diperoleh dari Data yang diperoleh dalam penelitian ini adalah data kuantitatif yang dianalisis dengan analisis statistik deskriptif untuk mendeskripsikan data kemampuan membaca dan menulis aksara Sunda siswa. Analisis statistik yang akan digunakan berupa uji normalitas, uji homogenitas, dan uji hipotesis.

Uji normalitas dilakukan untuk mengetahui sebaran data hasil belajar membaca aksara Sunda pada kelas eksperimen dengan menggunakan analisis Chi-Square dan uji homogenitas dilakukan untuk mengetahui apakah kemampuan awal dan akhir membaca dan menulis aksara Sunda di kelas eksperimen homogen atau tidak homogen. Ada tidaknya pengaruh metode iqra dalam pembelajaran membaca aksara Sunda terhadap kemampuan menulis aksara Sunda dilakukan uji gain, sedangkan uji hipotesis dilakukan untuk mengetahui apakah hipotesis yang telah diajukan diterima atau ditolak.

\section{HASIL DAN PEMBAHASAN}

Pada tes awal membaca, dapat diketahui bahwa kemampuan awal membaca aksara Sunda Siswa masih rendah. Berdasarkan aspek membaca (Humam, 2000) kemampuan membaca siswa tergolong sangat lambat, jumlah kata yang benar minim, sering salah dalam intonasi dan artikulasi fonem, dan volume suara yang diucapkan nyaris tidak terdengar. Hal ini dibuktikan dengan hasil tes kemampuan awal membaca aksara Sunda siswa $100 \%$ tidak tuntas/tidak mencapai KKM $(\mathrm{KKM}=70)$. 
Tabel 2. Distribusi Frekuensi Tes Awal Membaca Aksara Sunda Siswa Kelas X AK SMK Pasundan Subang

\begin{tabular}{|c|c|c|c|c|c|}
\hline No. & Kelas Interval & f & $\mathbf{x}$ & f.x & $\%$ \\
\hline 1 & $28-33$ & 10 & 30,5 & 305 & 27,78 \\
\hline 2 & $34-39$ & 8 & 36,5 & 292 & 22,22 \\
\hline 3 & $40-45$ & 10 & 42,5 & 425 & 27,78 \\
\hline 4 & $46-51$ & 3 & 48,5 & 145,5 & 8,33 \\
\hline 5 & $52-57$ & 1 & 54,5 & 54,5 & 2,78 \\
\hline 6 & $58-63$ & 4 & 60,5 & 242 & 11,11 \\
\hline & Jumlah & 36 & 273 & 1464 & 100 \\
\hline \multicolumn{6}{|c|}{ Nilai Rata-rata 40,33 } \\
\hline \multicolumn{6}{|c|}{ Nilai Tertinggi 60} \\
\hline \multicolumn{6}{|c|}{ Nilai Terendah 28} \\
\hline
\end{tabular}

Berdasarkan tabel di atas, diperoleh data kemampuan awal membaca aksara Sunda, nilai terendah yang dicapai siswa adalah 20, sedangkan nilai kemampuan membaca aksara Sunda tertinggi adalah 60 . siswa yang mendapat nilai $\geq 70$ berjumlah 0 siswa sedangkan yang mendapat nilai $<70$ sebanyak 36 siswa atau $100 \%$ tidak tuntas, dengan nilai rata-rata tes kemampuan awal membaca aksara Sunda yaitu 40,33.

Pada tes awal menulis, kemampuan menulis aksara Sunda siswa masih rendah. Bedasarkan aspek penilaian menulis, aspek benar dan tidaknya menulis aksara vokal tergolong rendah dengan nilai rata-rata 2,49 , aspek benar dan tidaknya menulis aksara konsonan dan angka tergolong rendah dengan nilai rata-rata 1,71 , aspek benar dan tidaknya menulis vokalisasi aksara Sunda tergolong sedikit, dan aspek kerapiannya tergolong sedikit rapi. Hal ini dibuktikan dengan hasil tes kemampuan awal menulis aksara Sunda siswa 92\% tidak tuntas, $8 \%$ tuntas.

Tabel 3. Distribusi Frekuensi Tes Awal Menulis Aksara Sunda Siswa Kelas X AK SMK Pasundan Subang

\begin{tabular}{|c|c|c|c|c|c|}
\hline No. & Kelas Interval & f & $\mathbf{x}$ & f.x & $\%$ \\
\hline 1 & $20-28$ & 11 & 24 & 264 & 30,56 \\
\hline 2 & $29-37$ & 9 & 33 & 297 & 25 \\
\hline 3 & $38-46$ & 10 & 42 & 420 & 27,78 \\
\hline 4 & $47-55$ & 4 & 51 & 204 & 11,1 \\
\hline 5 & $56-64$ & 1 & 60 & 60 & 2,78 \\
\hline 6 & $65-73$ & 1 & 69 & 69 & 2,78 \\
\hline & Jumlah & 36 & 279 & 1314 & 100 \\
\hline \multicolumn{6}{|c|}{ Nilai Rata-rata 40,78 } \\
\hline \multicolumn{6}{|c|}{ Nilai Tertinggi 72} \\
\hline
\end{tabular}

Berdasarkan tabel 2 di atas, diperoleh data kemampuan awal menulis aksara Sunda, nilai terendah yang dicapai siswa adalah 20, sedangkan nilai kemampuan menulis aksara Sunda tertinggi adalah 72 . siswa yang mendapat nilai $\geq 70$ berjumlah 1 orang siswa sedangkan yang mendapat nilai $<70$ sebanyak 35 siswa. atau $92 \%$ tidak tuntas, dengan nilai rata-rata tes kemampuan awal menulis aksara Sunda yaitu 40,78 .

Berdasarkan keterangan di atas, kemampuan membaca dan menulis aksara Sunda sebelum menggunakan metode iqra masih rendah. Setelah digunakannya metode iqra dalam pembelajaran membaca aksara Sunda, kemampuan membaca aksara Sunda siswa meningkat secara signifikan. 
Metode iqra ini berpengaruh pula terhadap kemampuan menulis aksara Sunda Siswa.

Tabel 4. Distribusi Frekuensi Tes Akhir Membaca Aksara Sunda Siswa Kelas X AK SMK Pasundan Subang

\begin{tabular}{|c|c|c|c|c|c|}
\hline No. & Kelas Interval & $\mathbf{f}$ & $\mathbf{x}$ & f.x & $\%$ \\
\hline 1 & $60-66$ & 2 & 63 & 126 & 5,56 \\
\hline 2 & $67-73$ & 1 & 70 & 70 & 2,780 \\
\hline 3 & $74-80$ & 4 & 77 & 308 & 11,11 \\
\hline 4 & $81-87$ & 9 & 84 & 756 & 25 \\
\hline 5 & $88-94$ & 13 & 91 & 183 & 36,11 \\
\hline 6 & 95-104 & 7 & 98 & 686 & 19,44 \\
\hline & Jumlah & 36 & 483 & 3129 & 100 \\
\hline \multicolumn{6}{|c|}{ Nilai Rata-rata 86,78 } \\
\hline \multicolumn{6}{|c|}{ Nilai Tertinggi 100} \\
\hline
\end{tabular}

Berdasarkan tabel 2 di atas diperoleh data kemampuan akhir membaca aksara Sunda, nilai terendah yang dicapai siswa adalah 60, dan nilai tertinggi adalah 100 . Siswa yang mendapat nilai $\geq 70$ berjumlah 33 siswa sedangkan yang mendapat nilai $<70$ sebanyak 3 siswa atau $92 \%$ dengan nilai rata-rata tes kemampuan ahir membaca aksara Sunda yaitu 86,78.

Ada perubahan kemampuan membaca aksara Sunda setelah digunakannya metode iqra. Kemampuan membaca dalam aspek waktu tergolong cepat, jumlah kata yang benar tergolong banyak, intonasi yang diucapkan tidak terdapat kesalahan, begitupun dari segi aspek artikulasinya, dan volume suara dalam membaca tergolong nyaring walaupun sebagian ada yang sedikit nyaring dalam membacanya.

Peningkatan kemampuan membaca aksara Sunda, sangat berpengaruh terhadap kemampuan menulis aksara Sunda. Hal ini terlihat dari hasil tes akhir menulis aksara Sunda setelah digunakannya metode iqra dalam pembelajaran membaca aksara Sunda.

Tabel 5. Distribusi Frekuensi Tes Akhir Menulis Aksara Sunda Siswa Kelas X AK SMK Pasundan Subang

\begin{tabular}{|c|c|c|c|c|c|}
\hline No. & Kelas Interval & f & $\mathbf{x}$ & f.x & $\%$ \\
\hline 1 & $60-66$ & 2 & 63 & 63 & 5,56 \\
\hline 2 & $67-73$ & 1 & 70 & 70 & 2,78 \\
\hline 3 & $74-80$ & 6 & 77 & 462 & 16,67 \\
\hline 4 & $81-87$ & 2 & 84 & 168 & 5,56 \\
\hline 5 & $88-94$ & 17 & 91 & 1547 & 47,22 \\
\hline 6 & $95-101$ & 8 & 98 & 784 & 22,21 \\
\hline & Jumlah & 36 & 483 & 3094 & 100 \\
\hline \multicolumn{6}{|c|}{ Nilai Rata-rata 86,78 } \\
\hline \multicolumn{6}{|c|}{ Nilai Tertinggi 100} \\
\hline
\end{tabular}

Berdasarkan tabel 4 di atas diperoleh data kemampuan akhir menulis aksara Sunda, nilai terendah yang dicapai siswa adalah 60, dan nilai tertinggi adalah 100 . Siswa yang mendapat nilai $\geq 70$ berjumlah 33 siswa sedangkan yang mendapat nilai $<70$ sebanyak 3 siswa atau $92 \%$ dengan nilai rata-rata tes kemampuan ahir membaca aksara Sunda yaitu 87,22.

Dari hasil tes kemampuan awal dan ahir membaca dan menulis aksara Sunda siswa kelas X AK SMK Pasundan Subang, diperoleh data berupa nilai kemampuan awal dan kemampuan akhir (prates dan 
postes) membaca dan menulis aksara Sunda. Data tersebut selanjutnya digunakan untuk menentukan besarnya n-Gain kemampuan awal dan akhir membaca dan menulis aksara Sunda. Untuk memudahkan dan melihat perbedaan nilai kemampuan awal dan akhir membaca dan menulis aksara Sunda, disajikan berupa grafik dalam gambar 1 untuk kemampuan awal dan akhir membaca aksara Sunda, dan dalam kemampuan awal dan akhir menulis aksara Sunda pada gambar 2.

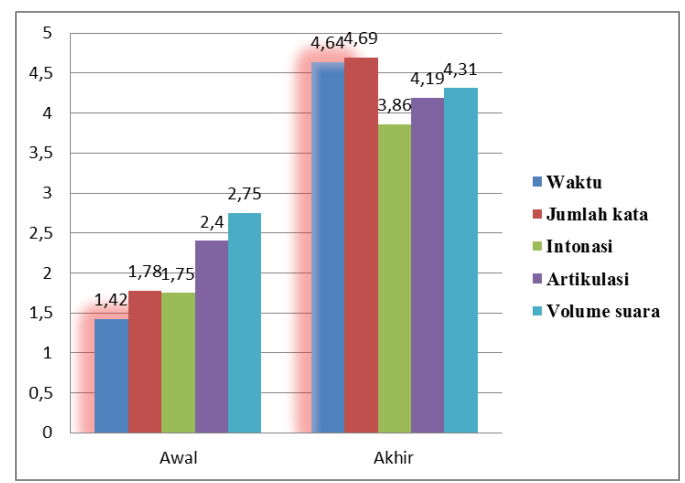

Gambar 1. Nilai rerata kemampuan awal dan akhir membaca aksara Sunda

Pada gambar 1 tampak bahwa rerata perolehan nilai kemampuan awal dan akhir membaca aksara Sunda sebelum dan sesudah menggunakan metode iqra dalam setiap aspek membaca meningkat. Nilai rerata kemampuan membaca aspek waktu meningkat sebesar 3,22, nilai rerata kemampuan membaca aspek jumlah kata meningkat sebesar 2,91, nilai rerata kemampuan membaca aspek intonasi meningkat 2,11, nilai rerata kemampuan membaca aspek artikulasi meningkat sebesar 1,79, dan nilai rerata kemampuan membaca aspek volume suara meningkat sebesar 1,19.

Nilai rerata kemampuan menulis aksara Sunda digunakan untuk mendapatkan nGain seperti yang disajikan dalam bentuk grafik dalam gambar 2.

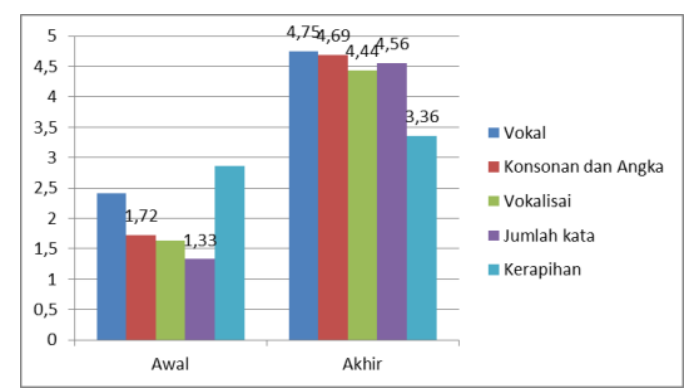

Gambar 2. Nilai rerata kemampuan awal dan akhir menulis aksara Sunda

Pada gambar 2 tampak nilai rerata perolehan nilai kemampuan awal dan menulis aksara Sunda setelah menggunakan metode iqra dalam pembelajaran membaca aksara Sunda dalam setiap aspek menulisnya meningkat. Nilai rerata kemampuan menulis aspek aksara vokal meningkat sebesar 2,23, nilai rerata kemampuan menulis aspek aksara konsonan dan angka meningkat sebesar 2,97, nilai rerata kemampuan menulis vokalisasi aksara Sunda meningkat sebesar 2,8 , nilai rerata kemampuan menulis aspek jumlah kata yang benar dalam menulis aksara Sunda meningkat sebesar 3,23, dan nilai rerata kemampuan menulis aspek kerapihan menulis aksara Sunda meningkat sebesar 0,5. 
Adanya peningkatan kemampuan menulis aksara Sunda setelah digunakannya metode iqra dalam pembelajaran membaca aksara Sunda terlihat dari hasil penilian aspek menulis aksara Sunda. Kemampuan akhir menulis aksara Sunda aspek benar dan tidaknya nulis aksara swara tergolong sangat tinggi, aspek benar dan tidaknya menulis aksara konsonan sangat tinggi, aspek benar dan tidaknya menulis vokalisasi aksara Sunda tergolong tinggi, aspek jumlah kata yang benar tergolong tinggi, dan aspek kerapihan tergolong sedang.

Kemampuan menulis dalam aspek kerapihan dalam menulis aksara Sunda merupakan aspek yang terendah berdasarkan nilai rata-ratanya yaitu 3,36.Hal ini disebabkan karena waktu penelitian yang tergolong singkat. Seiring berjalannya waktu, kemampuan menulis aksara Sunda aspek kerapian dalam menulis aksara Sunda siswa akan meningkat lagi.

Untuk menentukan perbedaan kemampuan membaca dan menulis aksra Sunda sebelum dan sesudah menggunakan metode iqra diperlukan uji sipat data (uji normalitas, uji homogenitas, uji gain, dan uji hipotesis).

Uji normalitas dilakukan untuk mengetahui normal atau tidaknya distribusi data kemampuan membaca dan menulis aksara Sunda sebelum dan sesudah digunakannya metode iqra. Dari uji normalitas kemampuan awal membaca aksara Sunda, dihasilkan $X^{2}$ hitung $=-54,86$ dan $X_{\text {tabel }}^{2}=7,81$. Berdasarkan hasil $X^{2}$ hitung $\leq X^{2}$ hitung, uji normalitas kemampuan awal menulis aksara Sunda dihasilkan $X^{2}$ hitung $=$ 22,54 dan $X_{\text {tabel }}^{2}=7,81$, uji normalitas kemampuan akhir membaca aksara Sunda, dihasilkan $X^{2}$ hitung $=-63,31$ dan $X_{\text {tabel }}^{2}=$ 7,81, dan uji normalitas kemampuan akhir menulis aksara Sunda siswa kelas X AK SMK Pasundan Subang dihasilkan $X^{2}$ hitung $=$ $-65,30$ dan $X^{2}$ tabel $=7,81$. Berdasarkan hasil yang diperoleh, uji normalitas kemampuan awal dan akhir membaca dan menulis aksara Sunda adalah $X^{2}$ hitung $\leq X^{2}$ tabel, distribusi nilai kemampuan awal dan akhir membaca dan menulis aksara Sunda adalah normal.

Selanjutnya dilakukan uji homogenitas dengan kriteria pengujian Tolak $\mathrm{H}_{\mathrm{o}}$ jika $F_{\text {hitung }} \geq F_{\text {tabel. }}$. Hasil dari pengujian homogenitas ini yang kemudian digunakan dalam penentuan rumusan yang dipakai untuk melakukan uji-t.

Berdasarkan hasil uji homogenitas yang dilakukan, dihasilkan $F_{\text {hitung }}=1,06$ dan $\mathrm{F}_{\text {tabel }}=1,76$ pada kemampuan awal dan kemampuan akhir membaca aksara Sunda. Sedangkan uji homogenitas dalam kemampuan awal dan akhir menulis aksara Sunda dihasilkan $F_{\text {hitung }}=1,39$ dan $F_{\text {tabel }}=$ 1,76. Karena $F_{\text {hitung }} \leq F_{\text {tabel }}$ maka $H_{0}$ diterima, artinya data penelitian mempunyai variansi yang homogen.

Setelah dilakukan perhitungan diperoleh nili $t_{\text {hitung }}$ sebesar 29,76 dan $t_{\text {tabel }}$ sebesar 2,03 pada kemampuan membaca aksara Sunda dan diperoleh nilai $t_{\text {hitung }}$ sebesar 20,57 dan $t_{\text {tabel }}$ sebesar 2,03 dengan menentukan taraf signifikasi 5\%. Karena $t_{\text {hitung }} \geq t_{\text {tabel }}, \mathrm{H}_{\mathrm{o}}$ diterima, $\mathrm{H}_{\mathrm{a}}$ ditolak. Artinya ada pengaruh metode iqra dalam pembelajaran membaca aksara Sunda terhadap kemampuan menulis aksara Sunda. Hal ini menunjukan bahwa Metode iqra dalam pembelajaran membaca aksara Sunda bisa meningkatkan kemampuan siswa dalam menulis aksara Sunda.

\section{SIMPULAN}

Berdasarkan hasil penelitian dan pembahasan, dapat disimpulkan bahwa digunakannya metode iqra dalam pembelajaran membaca aksara Sunda dapat meningkatkan kemampuan membaca aksara Sunda dan berpengaruh terhadap kemampuan menulis aksara Sunda.

Bedasarkan penelitian yang sudah dilakukan, disarankan bahwa metode iqra hendaknya diterapkan pada pembelajaran membaca dan menulis aksara Sunda, karena terbukti adanya peningkatan kemampuan 
membaca aksara Sunda, dan berpengaruh terhadap kemampuan menulis aksara Sunda. Agar pembelajaran membaca aksara Sunda dengan menggunakan metode iqra berjalan efektif, hendaknya guru menguasai kemampuan dalam membaca dan menulis aksara Sunda yang akan dibelajarkan, dan langkah-langkah pembelajaran membaca aksara Sunda dengan metode iqra, serta guru harus memiliki kreatifitas dalam merancang dan melaksanakan proses pembelajaran metode iqra berjalan dengan maksimal, hendaknya guru lebih memperhatikan pengelolaan waktu dalam proses pembelajaran.

\section{PUSTAKA RUJUKAN}

Arikunto, S. (2010a). Manajemen Penelitian. Jakarta: Rineka Cipta.

Humam, As'ad. (2000). Buku Iqra: Cara Cepat Membaca Al-Quran, Jilid 1-6. Yogyakarta: Balai Litbang LPTQ Nasional.
Peraturan Daerah Provinsi Jawa Barat Nomor 5 Tahun 2003 tentang Pemeliharaan Bahasa, Sastra, dan Aksara Daerah.

Peraturan Gubernur Nomor 69 Tahun 2013 tentang Pembelajaran Bahasa Daerah di Jawa Barat.

Peraturan Pemerintah RI No. 19 Tahun 2005 tentang Standar Nasional Pendidikan

Undang-Undang No. 20 Tahun 2003 tentang Sistem Pendidikan Nasional

\section{UCAPAN TERIMA KASIH}

Penulis mengucapkan terima kasih kepada berbagai pihak yang telah membantu dalam penelitian dan penulisan artikel ini. Umumnya kepada pihak Sekolah SMK Pasundan Subang, Kepala SMK Pasundan Subang, Rekan Guru, terutama untuk anak-anaku siswa kelas X AK SMK Pasundan Subang. 